\title{
The reverse dorsal metacarpal artery flap in finger reconstruction: A reliable choice
}

\author{
Jyoshid R. Balan, Shaji Mathew, Pradeep Kumar, Harsh Vardhan, Anto Francis, V. G. Aniljith, \\ Raj Gopal \\ Sushrutha Institute of Plastic Reconstructive and Aesthetic Surgery, Elite Mission Hospital, Thrissur, Kerala, India
}

Address for correspondence: Dr. Jyoshid R. Balan, Sushrutha Institute of Plastic Reconstructive and Aesthetic Surgery, Elite Mission Hospital, Thrissur - 680 007, Kerala, India. E-mail: drjosh4u@gmail.com

\begin{abstract}
Background: The finger skin and soft-tissue defects are reconstructive challenges due to their nature and the intricate extensor apparatus and flexors it protects. The reverse dorsal metacarpal artery (RDMA) is a time-tested option for the reconstruction of the same. Materials and Methods: A total of 14 cases of RDMA flap for finger defects involving proximal to distal phalanx were performed. Thirteen of these patients were male and one patient female and the most common mode of injury was occupational in nature followed by road traffic accident. The overall appearance was assessed for the flap and the donor site. The associated injuries and the range of motion were noted. Results: All but one flap survived completely. One patient had partial distal flap loss, which was tackled with split-thickness skin grafting. The flap size varied from $3.5 \mathrm{~cm} \times 1.5 \mathrm{~cm}$ to $9 \mathrm{~cm} \times 2 \mathrm{~cm}$ with mean of $6.64 \mathrm{~cm} \times 1.72 \mathrm{~cm}$. The mean age of the patients was 33.4 years. All the patients had acceptable aesthesis. The donor site had no complications and healed with linear scar. Conclusions: RDMA flap is a reliable flap for finger defects reconstruction. The range of movement mainly depends on the associated injury rather than flap transfer alone and to prove this we require doing analysis of range of movement in patients with flap done alone or with associated injuries.
\end{abstract}

\section{KEY WORDS}

Aesthesis; finger defects; reconstruction; reverse dorsal metacarpal artery flap

\section{INTRODUCTION}

The architecture and the engineering of finger is extraordinarily beautiful and very delicate. The dorsal skin is very thin, and it covers one of the nature's best-engineered creations, the extensor apparatus. The reconstruction of the dorsum finger

\begin{tabular}{|l|l|}
\hline \multicolumn{2}{|c|}{ Access this article online } \\
\hline Quick Response Code: & Website: \\
\hline & www.ijps.org \\
\cline { 2 - 2 } & Dol: \\
\hline
\end{tabular}

is challenging due to the tissue characteristics as well as the scarcity of possible available tissue. A plethora of flaps has been used for the reconstruction of soft-tissue defects of the fingers including homodigital, heterodigital, regional or distant flaps. Digital flaps are

This is an open access journal, and articles are distributed under the terms of the Creative Commons Attribution-NonCommercial-ShareAlike 4.0 License, which allows others to remix, tweak, and build upon the work non-commercially, as long as appropriate credit is given and the new creations are licensed under the identical terms.

For reprints contact: reprints@medknow.com

How to cite this article: Balan JR, Mathew S, Kumar P, Vardhan $\mathrm{H}$, Francis A, Aniljith VG, et al. The reverse dorsal metacarpal artery flap in finger reconstruction: A reliable choice. Indian J Plast Surg 2018;51:54-9. 
limited by the amount 'that Peter can pay' and frequently not possible for large defects. With refinements in microsurgery, free tissue transfer is becoming an attractive alternative for reconstruction. However, on a lower rung of the reconstructive ladder lies the regional flap. Among the locoregional options, the reverse dorsal metacarpal artery (RDMA) flap is very widely used for covering dorsal finger defects. ${ }^{[1,2]}$ It has been used as a cutaneous pedicled, subcutaneous tunnelled as well as propeller flap design for finger reconstruction. The thin characteristic of the dorsal hand skin gives an extra edge for RDMA flap over other options of the finger dorsum reconstruction. The vascular basis of the RDMA flap is well studied. For dorsal digital defects, they provide like-for-like cover. It provides reconstruction in a single stage, with minimal donor site morbidity. We present our experience of RDMA flap for the reconstruction of dorsal finger reconstruction.

\section{MATERIALS AND METHODS}

A total of 14 patients with finger defects with exposed tendon or bones were included in this study. Those patients with associated injury in the skin of the dorsum of hand in the area of the RDMA flap were excluded from the study. We had 13 male patients and 1 female patient, age of the patients ranging from 18 to 49 years with a mean age of 33.4 years. Among these patients, four patients sustained injury in road traffic accident, eight of the injuries occurred in the workplace, one patient admitted with assault and one patient had high voltage electrical injury. Six of these 14 patients had RDMA flap in the initial surgery itself, the rest of the patients the surgery was done after a waiting period to look for the survival of the finger skin. Islanded pedicle (propeller) flap was done in six patients. We had 4 patients with involvement of little finger, 4 ring fingers, 3 middle fingers and 3 index fingers. All of the patients had associated skeletal or tendon injuries except one patient. The associated injuries were in the form of flexor or extensor tendon injury, digital vessel injury, joint injury or phalangeal or metacarpal fracture. In the electrical injury patient, there was an associated palmar skin burn which was tackled by skin grafting, and the defect was over the ulnar side of the index finger with associated ulnar side digital vessel injury in the form of thrombosis with skin necrosis over the same. The defect size varied from $2 \mathrm{~cm} \times 1.5 \mathrm{~cm}$ to $8 \mathrm{~cm} \times 2 \mathrm{~cm}$ with a mean of $3.71 \mathrm{~cm} \times 1.81 \mathrm{~cm}$. Postoperatively, both the donor site and flap site were assessed for aesthesis.

\section{Surgical technique}

The procedure was performed under regional anaesthesia with tourniquet control. The flap is based upon the retrograde flow in the dorsal metacarpal artery, through the communication from the common digital artery on the volar side. The perforator vessel was identified with a handheld Doppler preoperatively [Figure 1a]. After completion of debridement, the pattern of the defect was made. Planning in reverse was done and the flap is marked [Figure 1a]. It was ensured that the distal-most part of the flap reached the tip of the defect without tension. Any tension in the flap results in vascular compromise and should be eliminated in the planning stage itself. The flap is raised according to the defect based either on the metacarpal head perforator or the web space perforator. Flap was elevated from a proximal to distal direction in the loose areolar tissue plane, just superficial to extensor tendon paratenon. The perforator vessel can be seen in most of the cases [Figure 1b]. Utmost care was taken not to injure the pedicle during elevation. After completion of elevation, the tourniquet was released and flap allowed to perfuse. Haemostasis was attained and primary closure of the donor site defect was done in all patients [Figure 1c]. The intervening skin between the flap and the defect was incised to accommodate the pedicle. The flap was then transferred onto the defect and inset given [Figure 1c]. Inset was tension free and kinking of the pedicle was excluded. The hand was immobilised in neutral position with a volar splint. We ensured that strict hand elevation has been done at least for 7 days' post-operative in all patients. The flap was monitored regularly for vascular compromise. If venous congestion was noted, few sutures were removed to decongest the flap and the patient monitored for a longer duration on an inpatient basis.

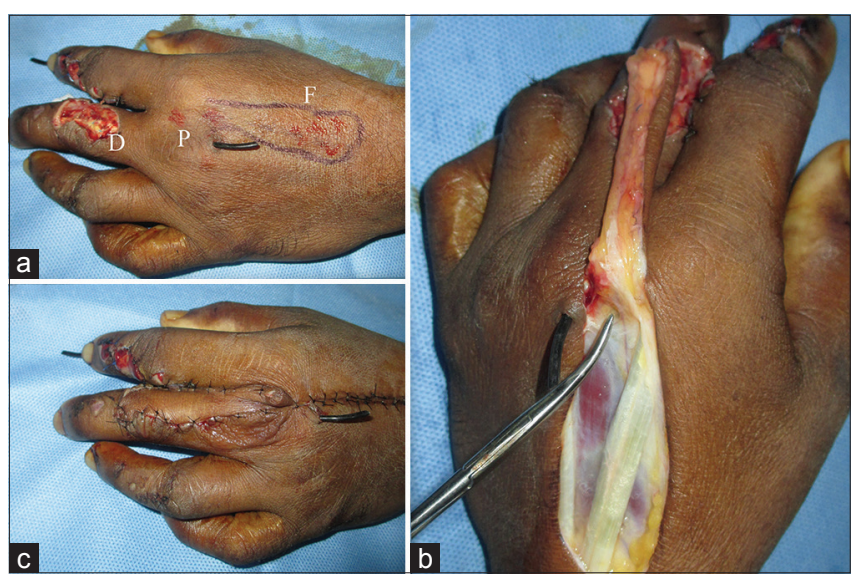

Figure 1: (a) Planning of reverse dorsal metacarpal artery flap, defect (D) perforator $(P)$ flap $(F)$. (b) Perforator vessel entering the elevated flap. (c) Flap inset and primary closure of the donor site 


\section{RESULTS}

A total of 14 patients underwent finger reconstruction with RDMA flap [Table 1], and all the flaps survived completely except one which had distal flap necrosis. Three flaps had venous congestion in the initial post-operative period survived by removal of few stitches and hand elevation. One of these three flaps had distal flap necrosis and was tackled by application of split-thickness skin grafting after a few days dressing. The flap size varied from $3.5 \mathrm{~cm} \times 1.5 \mathrm{~cm}$ to $9 \mathrm{~cm} \times 2 \mathrm{~cm}$ with mean of $6.64 \mathrm{~cm} \times 1.72 \mathrm{~cm}$. The mean age of the patients was 33.4 years. There was restriction of extension or flexion in five of the patients. These patients had associated

Table 1: Results of the study

\begin{tabular}{|c|c|c|c|c|c|c|c|c|c|c|}
\hline $\begin{array}{l}\text { Case } \\
\text { number }\end{array}$ & Age/sex & Cause & $\begin{array}{c}\text { Defect } \\
\text { size }(\mathrm{cm})\end{array}$ & $\begin{array}{c}\text { Flap } \\
\text { size }(\mathrm{cm})\end{array}$ & $\begin{array}{l}\text { Defect } \\
\text { location }\end{array}$ & $\begin{array}{l}\text { Associated } \\
\text { injury }\end{array}$ & Flap used & $\begin{array}{l}\text { Flap } \\
\text { execution } \\
\text { time } \\
\text { interval }\end{array}$ & $\begin{array}{l}\text { Aesthesis } \\
\text { flap and } \\
\text { donor }\end{array}$ & Complications \\
\hline 1 & 18/male & OCCUPATIONAL & $3.5 \times 1.5$ & $7.5 \times 1.5$ & $\begin{array}{l}\text { PPx LF, } \\
\text { volar }\end{array}$ & $\begin{array}{l}\text { Amputation } \\
\text { LF (PIPJ) }\end{array}$ & $\begin{array}{l}4^{\text {th }} \\
\text { RDMA (I) }\end{array}$ & $\begin{array}{l}2 \text { weeks } \\
4 \text { days }\end{array}$ & Good & Nil \\
\hline 2 & 35/male & OCCUPATIONAL & $3 \times 2$ & $6 \times 2$ & $\begin{array}{l}\text { Dorsum } \\
\text { PIPJ IF }\end{array}$ & $\begin{array}{l}\text { Extensor } \\
\text { expansion } \\
\text { injury }\end{array}$ & $2^{\text {nd }} R D M A$ & Immediate & Very good & Nil \\
\hline 3 & $32 /$ male & RTA & $5 \times 2.3$ & $6 \times 2.3$ & $\begin{array}{l}\text { Dorsum } \\
\text { proximal to } \\
\text { MPx RF }\end{array}$ & $\begin{array}{l}\text { Extensor } \\
\text { expansion } \\
\text { injury/PIPJ } \\
\text { injury }\end{array}$ & $3^{\text {rd }}$ RDMA & Immediate & Good & Nil \\
\hline 4 & 29/male & Electrical burns & $8 \times 2$ & $9 \times 2$ & $\begin{array}{l}\text { Dorsovolar } \\
\text { IF, from } \\
\text { base to } \\
\text { TIP }\end{array}$ & $\begin{array}{l}\text { Digital } \\
\text { vessal } \\
\text { injury }\end{array}$ & $2^{\text {nd }}$ RDMA & 3 weeks & Very good & Nil \\
\hline 5 & 44/male & Occupational & $5 \times 1.5$ & $7.5 \times 1.5$ & $\begin{array}{l}\text { Dorsovolar } \\
\text { MPx MF }\end{array}$ & $\begin{array}{l}\text { \#DPx RF, } \\
\text { \#MPX MF, } \\
\text { FDP TO MF }\end{array}$ & $\begin{array}{l}3^{\text {rd }} \\
\text { RDMA (I) }\end{array}$ & 2 weeks & Good & Nil \\
\hline 6 & 49/male & Occupational & $3 \times 1.5$ & $5.5 \times 1.5$ & $\begin{array}{l}\text { Dorsum } \\
\text { MF }\end{array}$ & $\begin{array}{l}\text { \#DPx MF, } \\
\text { extensor } \\
\text { expansion } \\
\text { injury }\end{array}$ & $2^{\text {nd }} \mathrm{RDMA}$ & 2 weeks & Good & $\begin{array}{l}\text { Venous } \\
\text { congestion }\end{array}$ \\
\hline 7 & 46/male & Occupational & $2 \times 1$ & $5.5 \times 1$ & $\begin{array}{l}\text { Dorsum LF } \\
\text { PPx }\end{array}$ & $\begin{array}{l}\text { Extensor } \\
\text { expansion } \\
\text { injury }\end{array}$ & $\begin{array}{l}4^{\text {th }} \\
\text { RDMA (I) }\end{array}$ & 4 weeks & Good & Nil \\
\hline 8 & 23/male & RTA & $3.5 \times 2$ & $4.5 \times 2$ & $\begin{array}{l}\text { Dorsum } \\
\text { LF, PIPJ }\end{array}$ & $\begin{array}{l}\text { Extensor } \\
\text { expansion } \\
\text { injury }\end{array}$ & $4^{\text {th }}$ RDMA & Immediate & Very good & Nil \\
\hline 9 & 40/male & Occupational & $2 \times 1.5$ & $3.5 \times 1.5$ & $\begin{array}{l}\text { LF dorsum } \\
\text { PPx }\end{array}$ & \#PPx LF & $4^{\text {th }}$ RDMA & Immediate & Very good & Nil \\
\hline 10 & 38/female & Assault & $3 \times 1.5$ & $5 \times 1.5$ & MF PPx & \#PPx MF & $\begin{array}{l}2^{\text {nd }} \\
\text { RDMA (I) }\end{array}$ & 2 weeks & Acceptable & NIL \\
\hline 11 & $22 /$ male & Occupational & $5 \times 2.5$ & $7.5 \times 1.2$ & $\begin{array}{l}\text { Dorsum } \\
\text { PIPJ RF }\end{array}$ & $\begin{array}{l}\text { Amputation } \\
\text { RF }\end{array}$ & $\begin{array}{l}3^{\text {rd }} \\
\text { RDMA (I) }\end{array}$ & Immediate & Acceptable & Nil \\
\hline 12 & 29/male & Occupational & $3 \times 2$ & $6 \times 2$ & $\begin{array}{l}\text { Dorsum } \\
\text { PPx RF }\end{array}$ & $\begin{array}{l}\text { Near total } \\
\text { amputation } \\
\text { RF/FDP, } \\
\text { FDS/digital } \\
\text { nerve/ } \\
\text { thenar } \\
\text { muscles } \\
\text { injury }\end{array}$ & $3^{\text {rd }}$ RDMA & 2 weeks & Very good & Nil \\
\hline 13 & 40/male & RTA & $3 \times 2$ & $5.5 \times 2$ & RF PPx & $\begin{array}{l}\# 3 \text { and } 4 \\
\text { MC/\#PPx } \\
\text { RF }\end{array}$ & $3^{\text {rd }}$ RDMA & 2 weeks & Good & $\begin{array}{l}\text { Venous } \\
\text { congestion } \\
\text { and partial flap } \\
\text { loss }\end{array}$ \\
\hline 14 & 23/male & Occupational & $3 \times 2$ & $5 \times 2$ & $\begin{array}{l}\text { IF } \\
\text { amputation } \\
\text { stump }\end{array}$ & $\begin{array}{l}\text { Crush injury } \\
\text { middle } \\
\text { finger }\end{array}$ & $2^{\text {nd }}$ RDMA & Immediate & Acceptable & $\begin{array}{l}\text { Venous } \\
\text { congestion }\end{array}$ \\
\hline
\end{tabular}

PPx: Proximal phalanx, MPx: Middle phalanx, DPx: Distal phalanx, PIPJ: Proximal inter phalangeal joint, FDP: Flexor digitorum profundus, FDS: Flexor digitorum superficialis, IF: Index finger, MF: Middle finger, RF: Ring finger, LF: Little finger, RDMA: Reverse dorsal metacarpal artery, RTA: Road traffic accident, MC: Metacarpal bone, \#: Fracture 
tendon or joint injuries [Table 1]. The aesthesis of both the donor as well as the flaps was acceptable.

\section{Case 1}

A 32-year-old man presented with crush injury of the left ring finger following a road traffic accident. Local examination showed dorsal skin deficit over the proximal phalanx till distal interphalangeal joint associated with extension expansion injury and open proximal interphalangeal joint [Figure 2a]. The wound was debrided the joint capsule and extensor expansion repaired. The raw area was covered with $3^{\text {rd }}$ RDMA flap planned in reverse [Figure $2 \mathrm{~b}$ and $\mathrm{c}$. The post-operative period was uneventful and the flap settled well [Figure $2 \mathrm{~d}$ ]. There was a minimal flexion deficit for the patient.

\section{Case 2}

A 29-year-old man with occupational injury to left hand in the form of laceration volar aspect with thenar muscles flexors to index, middle and ring finger cut, divided digital nerves to index middle and ring finger with near total amputation of the ring finger [Figure 3a]. He had absent flexor digitorum profundus (FDP) of the ring finger. In the initial procedure, we fixed the ring finger with revascularisation and repaired all the digital nerves, tendons and thenar muscles [Figure 3b]. There was partial necrosis of the dorsal skin of the ring finger which was debrided [Figure 3c]. The defect was covered with $3^{\text {rd }}$ RDMA flap [Figure $3 \mathrm{~d}$ and e]. The flap settled well with time giving good aesthesis of the finger as well as the donor site [Figure 3f]. The patient had flexion deficit, part due to absent flexor digitorum profundus to the digit and part due to the associated injuries.

\section{DISCUSSION}

Finger injury with exposed bones, tendon or neuromuscular bundles is frequently encountered in the plastic surgery emergency department. The ideal cover is one which gives best aesthetic as well as the functional outcome. The skin over the dorsum of the finger is thin and pliable; because of this, its reconstruction is also challenging. The options of reconstruction of finger defects vary from local flaps to free tissue transfer. ${ }^{[3]}$ For small defects dorsal rotation, advancement, transposition and hatchet flaps are described so far. ${ }^{[4-8]}$ For moderate defects cross finger flap, especially the adipofascial variant is commonly used. ${ }^{[9]}$ For dorsum of the fingers, the use of free tissue transfer is reserved for bigger defects, unlike for volar

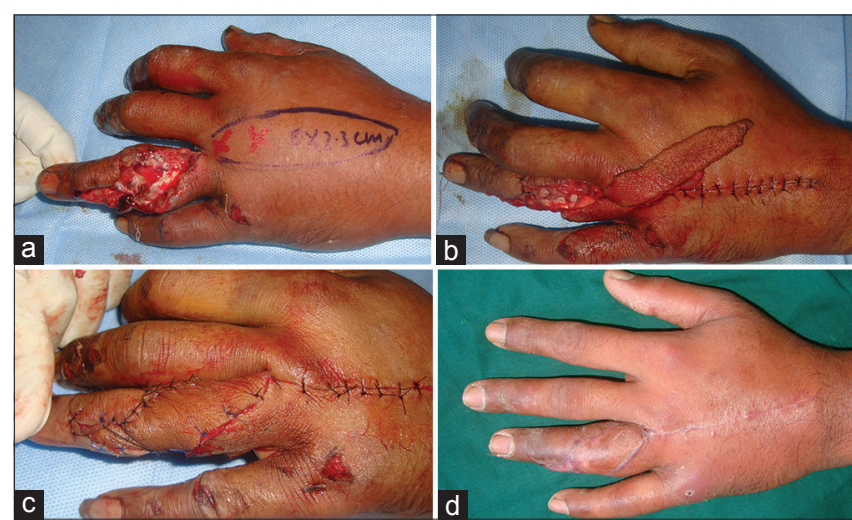

Figure 2: (a) Defect over the ring finger with extensor expansion injury and flap marking with marked perforator. (b) Repaired extensor expansion and the elevated $3^{\text {rd }}$ reverse dorsal metacarpal artery flap. (c) Complete inset of the flap. (d) 3 months' post-operative picture showing well-settled flap

and fingertip defects. Arterialised venous flaps are also used for large dorsal finger defect associated with dorsal hand defects especially when the local options are not available. ${ }^{[10]}$ The RDMA flap is a well-described entity for the finger defect reconstruction. It was first described in literature by Maruyama and Quaba in 1990..$^{[1,2]}$ The use of proximally based dorsal metacarpal artery flap for the finger reconstruction is also described in the literature. ${ }^{[11]}$

The dorsal finger and hand arterial anatomy is well studied. ${ }^{[12-14]}$ Beldame et al. in their anatomical study of the dorsal metacarpal arterial system and their communication clearly depicts the intercommunication of the palmar digital vessels and the dorsal metacarpal arteries. They also noticed the inconsistency of the metacarpal artery of the $3^{\text {rd }}$ and $4^{\text {th }}$ intermetacarpal spaces. Another finding in their study is the numerous plexiform communications of vessels especially distal to the juncturae tendinum. ${ }^{15]}$ In another cadaveric study by Yoon et al. showed that even though in the presence of consistent $4^{\text {th }}$ dorsal metacarpal artery the skin perforators were inconstant. Their dye injection study showed that the reverse dorsal metacarpal flap can be elevated without including the dorsal metacarpal artery or the interosseous muscle fascia. ${ }^{[16]}$ The picture got clearer by the study of Omokawa et al. They showed the parallel orientation of the $1^{\text {st }}$ through $5^{\text {th }}$ dorsal metacarpal arteries. The origin of $1^{\text {st }}$ and $2^{\text {nd }}$ DMA are from the radial artery and the dorsal metacarpal arch and the rest from the communicating branch from the palmar arteries at the metacarpal base. The basis of the RDMA flap is the communication between the palmar arteries and the dorsal arteries. These communications are more in the radial flaps than the ulnar side flaps. The 


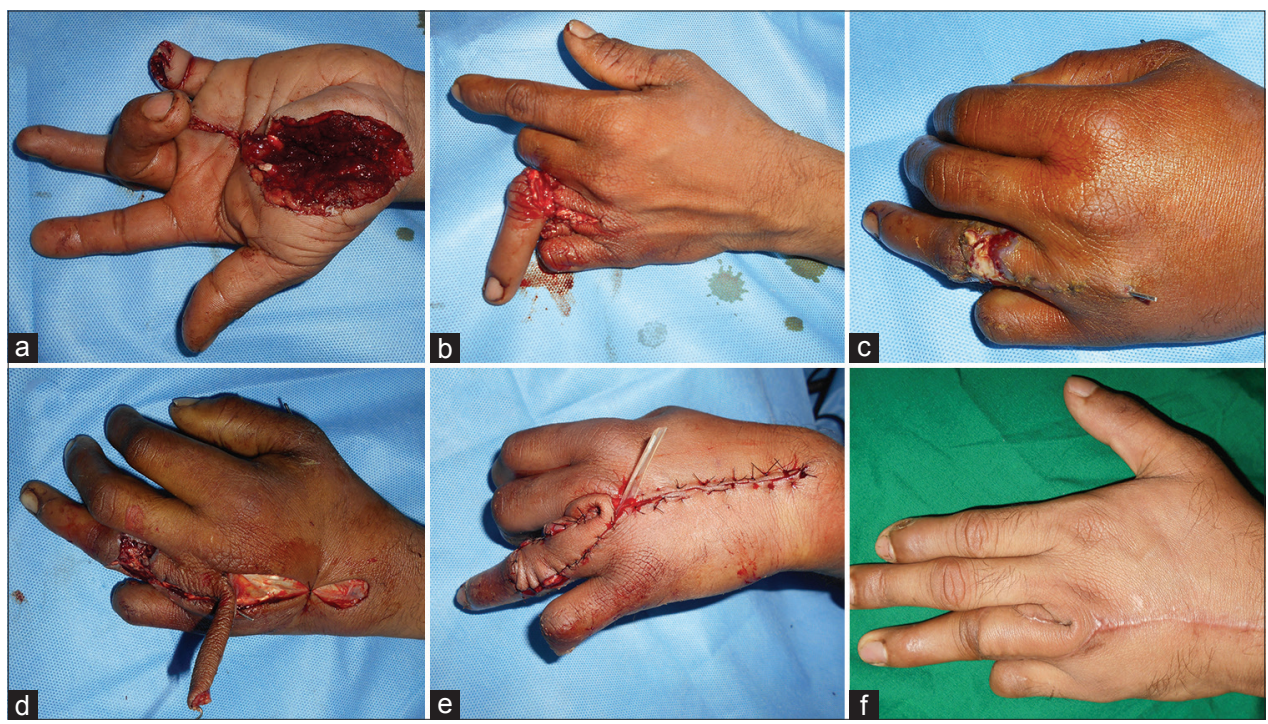

Figure 3: $(a$ and b) Extensive machine cut injury left hand involving the palm and near total amputation of the ring finger. (c) Necrotic area over the proximal interphalangeal joint left ring finger post-debridement. (d) Elevated $3^{\text {rd }}$ reverse dorsal metacarpal artery flap. (e) Flap inset. (f) 5 months post-operative result showing well-settled flap and good donor site scar

$1-3^{\text {rd }}$ DMA consistently communicates with the palmar arteries when compared to the $4^{\text {th }}$ and $5^{\text {th }}$ DMA. ${ }^{[17]}$ In our study, we were able to get the perforator by hand-held Doppler analysis. We planned all our flaps based on the perforator vessel.

The thin pliable characteristics of this flap have been used by Sebastin et al. in their study to cover finger defects proximal to the fingertip. They used 60 RDMA flaps in 56 patients and of which 21 flaps were used to cover defects distal to the proximal interphalangeal joints. They noticed that the complication can be in the form of venous congestion as well as arterial insufficiency. In larger defects, they were forced to use skin grafting over the donor defects. ${ }^{[18]}$ They have also mentioned that the flap can be elevated to the distal extension of extensor retinaculum. In our experience, if we keep the distal limit of the flap to the distal part of extension expansion, we will be able to take a flap of up to $9 \mathrm{~cm}$ length; it also depends on the size of the hand. In our cases, the tissue requirements were relatively less enabling primary closure of the donor site. The late post-operative results showed well healed linear scar over the dorsum of the hand. Koch et al. used the extended RDMA flap based on the communication at the proximal phalanx level in 12 patients and came out with good results. They have reported complication in the form of venous congestion in two patients of which one sustained partial flap loss. We also encountered complication in the form of venous congestion in three patients and had a partial flap loss in one of them.
In their series, they used subcutaneous pedicle and tunnelling of the pedicle. There was no restriction of passive or active range of movement in any patients while comparing with the counterpart in the normal hand. ${ }^{[19]}$ We noticed that there was restriction of movements in some patients mainly attributed due to the associated tendon or joint injury they sustained in the primary trauma. The joint movements mainly depends on associated bone or tendon injuries and not on flap transfer only, since the RDMA is thin and pliable flap.

Wang et al. in their experience showed that RDMA flap from the $2^{\text {nd }}$ and $3^{\text {rd }}$ intermetacarpal space are very viable option for the reconstruction of the distal and middle segment finger defects. ${ }^{[20]}$ Gregory et al. in their experience, noticed infection as one of the factors making the flap fail along with the venous congestion. They used both classic RDMA flap as well as extended flap in their patient population of 69. They had complication in 10 patients, seven had partial loss and three patients had complete flap loss. ${ }^{[21]}$ In our experience, the complications were mainly in the form of venous congestion, especially in extended RDMA flaps. The initial management of venous congestion as in any flaps is the removal of few stitches and observation. In one patient, we had distal flap necrosis which was tackled by split-thickness skin grafting after a few days' dressings. Venous congestion is a major issue of RDMA flap like any other distally based reverse flow flap. ${ }^{.22]}$ Vascularised bone transfer is also possible along with 
the DMA flap from the corresponding metacarpal bone, more with the $2^{\text {nd }}$ DMA flap. ${ }^{\text {[3-26] }}$

\section{CONCLUSIONS}

The RDMA flap is an excellent choice for the reconstruction of dorsal finger defects. The range of movement is mainly dependent on the associated injury rather than the flap transfer alone. We require doing a study comparing RDMA flap done for finger defect with and without associated injury to get make a non-confounded objective assessment of the functional outcome.

\section{Declaration of patient consent}

The authors certify that they have obtained all appropriate patient consent forms. In the form the patient(s) has/have given his/her/their consent for his/her/their images and other clinical information to be reported in the journal. The patients understand that their names and initials will not be published and due efforts will be made to conceal their identity, but anonymity cannot be guaranteed.

\section{Financial support and sponsorship}

Nil.

\section{Conflicts of interest}

There are no conflicts of interest.

\section{REFERENCES}

1. Maruyama Y. The reverse dorsal metacarpal flap. Br J Plast Surg 1990;43:24-7.

2. Quaba AA, Davison PM. The distally-based dorsal hand flap. $\mathrm{Br}$ J Plast Surg 1990;43:28-39.

3. Balan JR. Free toe pulp flap for finger pulp and volar defect reconstruction. Indian J Plast Surg 2016;49:178-84.

4. Jiao $H$, Ding $X$, Liu $Y$, Zhang $H$, Cao $X$. Clinical experience of multiple flaps for the reconstruction of dorsal digital defects. Int J Clin Exp Med 2015;8:18058-65.

5. Rehim SA, Kowalski E, Chung KC. Enhancing aesthetic outcomes of soft-tissue coverage of the hand. Plast Reconstr Surg 2015;135:413e-28e.

6. Eberlin KR, Chang J, Curtin CM, Sammer DM, Saint-Cyr M, Taghinia AH, et al. Soft-tissue coverage of the hand: A case-based approach. Plast Reconstr Surg 2014;133:91-101.

7. Chen SL, Chou TD, Chen SG, Cheng TY, Chen TM, Wang HJ, et al. The boomerang flap in managing injuries of the dorsum of the distal phalanx. Plast Reconstr Surg 2000;106:834-9.

8. Chen $C$, Tang P, Zhang $X$. The dorsal homodigital island based on the dorsal branch of the digital Artery: A review of 166 cases. Plast Reconstr Surg 2014;133:519e-29.
9. Al-Qattan MM. The cross-digital dorsal adipofascial flap. Ann Plast Surg 2008;60:150-3.

10. Yan H, Fan C, Zhang F, Gao W, Li Z, Zhang X, et al. Reconstruction of large dorsal digital defects with arterialized venous flaps: Our experience and comprehensive review of literature. Ann Plast Surg 2013;70:666-71.

11. Zhang $X$, He $Y$, Shao $X$, Li Y, Wen S, Zhu H, et al. Second dorsal metacarpal artery flap from the dorsum of the middle finger for coverage of volar thumb defect. J Hand Surg Am 2009;34:1467-73.

12. de Rezende MR, Mattar R Jr., Cho AB, Hasegawa OH, Ribak S. Anatomic study of the dorsal arterial system of the hand. Rev Hosp Clin Fac Med Sao Paulo 2004;59:71-6.

13. Yang D, Morris SF. Reversed dorsal digital and metacarpal island flaps supplied by the dorsal cutaneous branches of the palmar digital artery. Ann Plast Surg 2001;46:444-9.

14. Braga-Silva J. Anatomic basis of dorsal finger skin cover. Tech Hand Up Extrem Surg 2005;9:134-41.

15. Beldame J, Havet E, Auquit-Auckbur I, Lefebvre B, Mure JP, Duparc $\mathrm{F}$, et al. Arterial anatomical basis of the dorsal digito-metacarpal flap for long fingers. Surg Radiol Anat 2008;30:429-35.

16. Yoon TS, Carrera A, Benito-Ruiz J, Ferreres A, Serra-Renom JM. The anatomic basis of the fourth dorsal metacarpal flap: A cadaveric dissection. J Hand Surg Am 2006;31:711-6.

17. Omokawa S, Tanaka Y, Ryu J, Kish VL. The anatomical basis for reverse first to fifth dorsal metacarpal arterial flaps. J Hand Surg $\mathrm{Br}$ 2005;30:40-4.

18. Sebastin SJ, Mendoza RT, Chong AK, Peng YP, Ono S, Chung KC, et al. Application of the dorsal metacarpal artery perforator flap for resurfacing soft-tissue defects proximal to the fingertip. Plast Reconstr Surg 2011;128:166e-178e.

19. Koch H, Bruckmann L, Hubmer M, Scharnagl E. Extended revere dorsal metacarpal artery flap: Clinical experience and donor site morbidity. J Plast Reconstr Aesthet Surg 2007;60:349-55.

20. Wang P, Zhou Z, Dong Q, Jiang B, Zhao X. Reverse second and third dorsal metacarpal artery flap for repair of distal and middle segment finger soft tissue match. J Reconstr Microsurg 2011;27:495-502.

21. Gregory H, Heitmann C, Germann G. The evolution and refinements of the distally based dorsal metacarpal artery (DMCA) flaps. J Plast Reconstr Aesthet Surg 2007;60:731-9.

22. Shen $\mathrm{H}$, Shen $Z$, Wang $\mathrm{Y}$, Zhang $\mathrm{K}$, Zhang Z, Dai $X$, et al. Extended reverse dorsal metacarpal artery flap for coverage of finger defects distal to the proximal interphalangeal joint. Ann Plast Surg 2014;72:529-36.

23. Bermel C, Saalabian AA, Horch RE, Dörfler A, Alexiou C, Lyer S, et al. Vascularization of the dorsal base of the second metacarpal bone: An anatomical study using $\mathrm{C}$-arm cone beam computed tomography. Plast Reconstr Surg 2014;134:72e-80e.

24. Dauphin N, Casoli V. The dorsal metacarpal arteries: Anatomical study. Feasibility of pedicled metacarpal bone flaps. J Hand Surg Eur Vol 2011;36:787-94.

25. Saalabian AA, Unglaub F, Horch RE, Kneser U. Free vascularized metacarpal bone graft combined with extended dorsal metacarpal artery flap for phalangeal bone and soft tissue loss: Case report. Arch Orthop Trauma Surg 2012;132:137-40.

26. Katz TL, Hunter-Smith DJ, Matthew Rozen W. Reverse second dorsal metacarpal artery vascularized bone flap for index distal bone loss: A case report. Microsurgery 2016;36:250-3. 